\title{
Comparison among three domestic Wastewater Treatment Plan in Semarang City
}

\author{
Hasan Ali M Ali ${ }^{1} \&$ Dr. Ing. Sudarno, S.T., MSc ${ }^{2}$
}

${ }^{1}$ Master Program of Environmental Science, School of Postgraduate Studies, Diponegoro University, Semarang - Indonesia
${ }^{2}$ the lecture Program of Environmental Science, School of Postgraduate Studies, Diponegoro University, Semarang - Indonesia

\begin{abstract}
-background: water is a crucial element to uphold the existence of human beings, food production, organism, and economic growth. The wastewater treatment system in the city of semarang almost completely implements an on-site system in which every house has its own treatment facility in the form of a septic tank. Aim of this study is to find out the management system of the communal wastewater and its chemical and biological features.Method: the study topic about domestic wastewater treatment plan in semarang city which include simpang lima presented in kpp gunung asri i (rw ix, rt Oi), kpp gunung asri ii (rw ix, rt 04) and kpp cempaka (rw xiii, rt 06) using geospatial data. Variables in this study are, chemical (ph, bod, cod), and biological (e-coli) parameters. Statistical analysis spss and excel to display percentages and graphs. Result: the lowest tds is in inlet samples taken from kpp gunung asri $i$ which is 152 ppm while the highest is middle samples taken from kpp gunung asri $i$ which is 1114 ppm. The lowest turbidity is in outlet samples taken from kpp gunung asri $i$ which is $8.2 \mathrm{ntu}$ while the highest is inlet samples taken from kpp gunung asri $i$ which is $159 \mathrm{ntu}$. The lowest ph is in inlet samples taken from kpp gunung asri $i$ which is 7.02 while the highest is outlet samples taken from kpp cempaka which is 7.46. The lowest tss is in outlet samples taken from kpp gunung asri i which is 185 while the highest is middle samples taken from kpp gunung asri $i$ which is 299. The lowest cod is in outlet samples taken from kpp cempaka which is 133.3 while the highest is inlet samples taken from kpp gunung asri $i$ which is 1203.3. The lowest bod is in outlet samples taken from kpp gunung asri i which is 70.2677 while the highest is inlet samples taken from kpp gunung asri $i$ which is 373.023. The lowest e-coli is in outlet samples taken from kpp gunung asri $i$ and kpp cempaka which is 0 while the highest is middle samples taken from kpp gunung asri $i$ which is 6400. Conclusion: the worst quality of wastewater is in inlet samples taken from kpp gunung asri $i$.
\end{abstract}

Keywords-domestic wastewater, treatment plan, semarang.

\section{INTRODUCTION}

Water is a natural resource that is very important for human survival. (Scalon, 2004). Water is a crucial element to uphold the existence of human beings, food production, organism, and economic growth. Hence, water must be managed appropriately (Sharifinia, 2016) (Halder, 2015). The current state of water quality control doesn't reach satisfaction because of the rapidly growing population and anthropogenic occurrence. (Sahu et al., 2016).

Recently, a huge number of cities over the world is encountering water shortage. However, water is needed for approximately $40 \%$ worldwide food supply used in manufacture.(Sharifinia,2016). (Saha et al., 2016).
Thus, obtaining clean and enough water to drink is a main right of all humans. One of the most widely used water sources by humans is the river. The river plays an important role in meeting the various needs of the household, environmental sanitation, agriculture, industry, tourism, fisheries, power generation, water quality control, flood distribution, and as a habitat for flora and fauna ecosystems. The amount of water available on earth is estimated at $96.5 \%$ in the form of sea water and fresh water, $1.7 \%$ in the form of polar ice, $1.7 \%$ in the form of ground water and $0.1 \%$ in the form of surface water and in the air (Khair et al. 2019). But, water that can be used directly by humans is only about $31.1 \%$ 
of the total amount of fresh water that is in rivers, lakes and reservoirs in nature. ( DR Maidment,1988)

Waste water treatment that so far has not yet reached the stage of thinking of the process of handling or reusing the waste. Waste management which so far has only been done by curative means, by treating waste water that is discharged into the environment. This method is less able to overcome the problem of waste water pollution because it can still cause environmental pollution. In order to reduce the potential for pollution due to domestic waste generated by the community, the government also undertakes efforts to manage wastewater both on site (local) or off site (centralized). The wastewater treatment system in the city of Semarang almost completely implements an on-site system in which every house has its own treatment facility in the form of a septic tank.

The city of Semarang, through coordination from the Central Java Settlement of Environmental Sanitation Development since 2005, has built communal wastewater service facilities in several residential areas, one of which is in the Program Development Document Program Community Based Urban Sanitation In 2013.

\subsection{Problem of the Research:}

The facilities that have been built need to get appropriate management in terms of operations and maintenance so that their performance can optimally process domestic waste. But in practice, the community only uses sanitation facilities and rarely does monitoring. The WWTP monitoring program is important to be carried out with the aim of knowing the WWTP performance in managing domestic waste, whether the efficiency remains or even decreases.

Regarding the efficiency of WWTPs, it is obtained by measuring the quality of wastewater in WWTPs within a certain period / periodically ( \pm 6 months). The efficiency of WWTPs is classified as fluctuating to the incoming debit of wastewater, wastewater quality and maintenance of WWTP itself.

Factors affecting the performance of wastewater treatment to produce a stable and consistent wastewater treatment system include, influent characteristics of wastewater, consumption of water usage, treatment capacity, materials and construction and management. And in this study, the writer will take a samples of wastewater in the Settler basin, the Anaerobic Baffled Reactor (ABR), and the Anaerobic Filter (AF) at the Simpang lima WWTP

\section{LITERATURE REVIEW}

\subsection{Definition of Domestic Waste}

Domestic wastewater is the biggest pollutants that enters the waters and contributes to increasing pollution. This is because $60-80 \%$ of the clean water used will be discharged into the environment as wastewater. The results of the national statistical analysis showed that $62.14 \%$ of households had access to proper sanitation, but the proportion of households that still discharged domestic wastewater into drains / drainage channels reached $46.7 \%$. The WWTP functions to treat and control domestic waste Domestic wastewater is flowed through the interceptor channel and then discharged into river in a clean condition, so that with the WWTP it is expected that the river will be free from pollution especially domestic wastewater.( AlObaidy,2015)

\subsection{Definition of Wastewater}

Wastewater is generated from the use of water for various human activities. Waste water is a source of pollutants originating from various sources. This wastewater comes from residences, institutions, commercial companies and industries. One type of pure wastewater that comes from daily human needs without industrial activity is domestic wastewater (Corcoran, 2010). Domestic and non-domestic wastewater has several characteristics according to the source, the characteristics of liquid waste can be classified into physical, chemical and biological characteristics (Tchobanoglous, 1991) The characteristics of this wastewater vary greatly, so it depends on the source of the wastewater. The time factor as well as the sampling method also affect the characteristics of wastewater. Damaging the environment the most dangerous part of domestic waste is pathogenic microorganisms that are in human feces, because it can transmit various diseases when it enters the human body.( Metcalf,2008). So to prevent and overcome the problem of water pollution in water bodies, standards for the quality of wastewater are made. Wastewater standard is a measure of boundaries or levels of pollutant elements and / or the amount of pollutant elements that are tolerated differences in wastewater that will be discharged or released into the water source of a business and / or activity.( Tchobanoglous,1991) The efforts made by the government to restrain the rate of pollution are by imposing the latest regulations on the quality of domestic wastewater.( WHO, 1993).

\subsection{Domestic Wastewater Parameter Test}

\subsection{1.. Chemical Parameters}

The chemical features that have been evaluating in domestic wastewater are as follows $\mathrm{Ph}$, Chemical oxygen demand and biological oxygen demand. 


\section{a. $\mathbf{p H}$}

$\mathrm{pH}$ is the relative activity of hydrogen ions in solution and is a measure of the acidity or base of a solution.( Boyd,1990) The amount of $\mathrm{pH}$ between $0-14$ where the $\mathrm{pH}$ below 7 is acidic and above 7 is alkaline and the $\mathrm{pH}$ value 7 is neutral. $\mathrm{pH}$ with a value of 6.5-8.2 is the optimum condition for living things. A pH that is too acidic or too alkaline will kill living things. Rainwater as a source of river water is naturally acidic $(\mathrm{pH}$ below 7.0) is usually around 5.6 but in some areas it rises to dangerous levels between 4.0 and $5.0 \mathrm{pH}$ due to pollutants in the atmosphere caused by carbon from combustion fossils in the air. Changing the $\mathrm{pH}$ value is made possible by pollution generated by industrial, domestic or natural conditions. River water in Indonesia generally has a pH value between 2 - 10. ( Boyd,1990)

\section{b. Chemical Oxygen Demand (COD)}

COD is the amount of oxygen needed to decompose all organic matter contained in water. COD sources come from the activities of the paper industry, leather tanning, sugar, cutting of fish canning meat, freezing shrimp, bread, milk, cheese and butter, domestic waste and others.(Khelmann, FJ, 2003) The presence of COD in the environment can have an impact on humans and the environment, including the large number of dead aquatic biota due to the low concentration of dissolved oxygen in water and it is increasingly difficult to get river water that meets the criteria as drinking water raw material. COD or Chemical Oxygen Demand or also called chemical oxygen demand is the amount of oxygen needed for waste material in the water so that it can be oxidized through chemical reactions. (Khelmann, FJ, 2003)

\section{c. Biochemical Oxygen Demand (BOD)}

BOD is the amount of dissolved oxygen in water used by bacteria for the oxidation process of organic materials such as carbohydrates, proteins, organic matter from natural sources and pollution and is expressed in $\mathrm{mg} / \mathrm{L}$ or (ppm). (Khelmann, FJ, 2003) Organic materials containing carbon and hydrogen from oxidation produce carbon dioxide and water. BOD value of the amount of dissolved oxygen in water used by bacteria for the oxidation process of organic materials such as carbohydrates, proteins, and organic matter from used to determine the level of pollution in a waters this is an indication that the oxidation process by bacteria occurs. Clean, usable water has sufficient oxygen levels and does not contain many bacteria which can be dangerous if consumed.

\subsubsection{Biological Parameters}

The biological parameters that tested in this study is E- coli in order to recognize the biological status in communal wastewater which involve E- coli;

a. E- coli

E. coli is a type of fecal coliform bacteria usually found in the intestines of animals and humans. E. coli is an abbreviation of Escherichia coli. E-coli bacteria in water come from pollution or contamination from animal and human feces. Dirt can contain many types of disease-causing organisms. Escherichia coli enterohemorrhagic (EHEK) is one of the pathogenic intestinal bacteria that can cause diarrhea, hemorrhagic colitis (HC), hemolitic-uremic syndrome (HUS). E. coli bacteria in this case can cause ongoing diarrhea and HUS. Considering the low level of environmental sanitation in developing countries, diarrheal disease caused by pathogenic E.coli bacteria becomes an important problem if an outbreak occurs. This toxin works by removing one adenine base from the 28S rRNA unit, thus stopping protein synthesis. Food contaminated with E. coli bacteria, especially EHEK, causes diarrhea accompanied by luminous, due to the SLT (Shiga like toxin) toxin it produces (Dadang, 2000). As a pathogen, Escherichia coli is well known for its ability to cause gastrointestinal disease in humans. Five classes (virotype) of E. coli include enteropathogenic E. coli (EPEC), enetero-aggregative E. coli (EaggEC), E. coli enteroinvation (EIEC), eneterohemorrhagic E. coli (EHEC) and each virotype has characteristics its own pathogenicity. EHEC has a moderate (ordinary) invasion power. They do not have colonization antigens, but their fimbria are thought to play a major role in activating the host. This bacterium does not attack the cell mucosa like Shigella, but the EHEC strain produces a toxin that is identical to that of Shigella dysentriae type 1 so that it is known as Shiga toxin or Verocytotoxin Escherichia coli (VTEC) (Suardana et al, 2007).

\subsection{Location and Period}

The location of the study in Semarang city, central of java between the latitudes between $110^{\circ} 25 \mathrm{E}$ And longitude $658 \mathrm{~s}$ The total of area of the $373.78 \mathrm{~km}^{2}$. The period of the study included three months, start from November until April. 


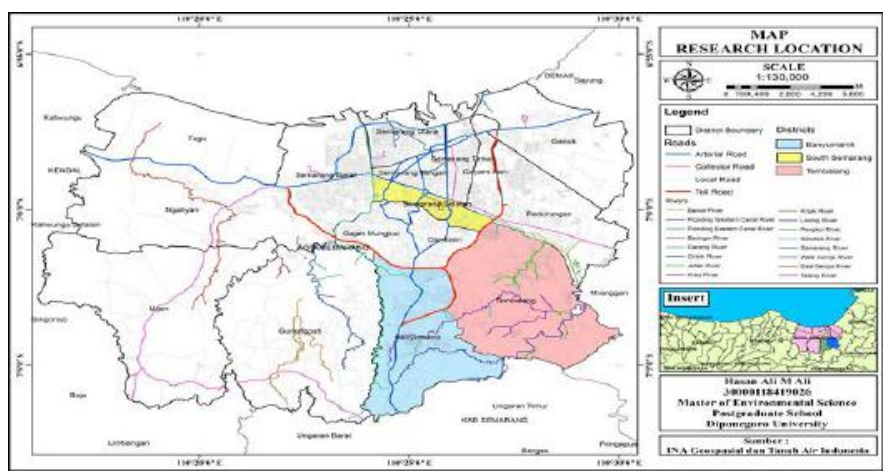

\subsection{Variables}

\subsubsection{Dependent Variables}

- The dependent variable includes, chemical and biological features of the communal, therefore the study has addressed three parameters from physical, chemical and biology respectively $\mathrm{Ph}, \mathrm{COD}, \mathrm{BOD}_{5}$ and $\mathrm{E}$ - coli.

1. $\mathrm{pH}$ is the relative activity of hydrogen ions in solution and is a measure of the acidity or base of a solution

2. COD is the amount of oxygen needed to decompose all organic matter contained in water.

3. BOD is the amount of dissolved oxygen in water used by bacteria for the oxidation process of organic materials such as carbohydrates,

4. E. coli is a type of fecal coliform bacteria usually found in the intestines of animals and humans

\subsubsection{Independent Variables}

The domestic wastewater is the primary source of the problem and acts as an independent variable.

\subsection{Data Collection Acquisition}

The research needs two kinds of data to achieve its purpose and it includes primary and secondary.

\subsubsection{Secondary Data}

The secondary data that used in this research are the followings: total number of household in respective area, number of the manhole, number of the household that have connected with manhole it was taken from bureau of statistic Semarang

\subsubsection{Primary Data}

1. Include the data of the environment that collected from the following methods six samples of the domestic wastes from the outlet to discharging area in Simpang Lima presented in;
2. Three (3) samples from KPP Gunung Asri I (RW IX, RT 0I).

3. Two (2) samples from KPP Cempaka (RW XIII, RT 06). And the study supposed to take three 3 but one of sample is solid.

4. While KPP Gunung Asri II (RW IX, RT 04) the study did not take samples because of the absent of the process.

5. Physical inspection: through observation the study will explore the method of manhole working

6. and the way of the domestic wastes going.

7. Global Positioning System (Ground survey): to determine the positions of domestic wastes and convert the data to maps for different purposes such as, distribution of the domestic waste locations, to understand the locations that have high concentration of wastes.

\subsection{Data Analysis}

The study is depending on several kinds of analysis are as:

1. The laboratory analysis: which include many kinds of instrument and method which are: $\mathrm{Ph}$ meter, turbidity meter, Gravimeter- Filter paper, Titration, Photometer Flame Photometer, Volumetric Flask, Place.

2. Statistical analysis SPSS and excel to display percentages and graphs.

3. Descriptive analysis to observe the phenomena of the ground

4. Geographic Information System

\section{RESULT AND DISCUSSION}

\section{A. Results}

Research on domestic wastewater treatment plans in the city of Semarang which includes Simpang Lima presented in KPP Gunung Asri I (RW IX, RT 0I), KPP Gunung Asri II (RW IX, RT 04) and KPP Cempaka (RW XIII, RT 06) using geospatial data. This study uses three (3) samples from KPP Gunung Asri I (RW IX, RT 0I) and two (2) samples from KPP Cempaka (RW XIII, RT 06) although three samples from KPP Cempaka should be taken but one sample is a sample solid. While the Gunung Asri II KPP (RW IX, RT 04) study did not take samples because there was no process. This study discusses three parameters from, chemical and biological, , $\mathrm{Ph}, \mathrm{COD}, \mathrm{BOD}$ and E-coli. The following are the results of the analysis for, chemical and biological parameters: 
Table 5.1. Result of Chemical and Biological Analysis

Note: ${ }^{*}=$ Sample from KPP Cempaka, ${ }^{* *}=$ Sample from KPP Gunung Asri I

\begin{tabular}{|l|l|l|l|l|l|}
\hline \multirow{2}{*}{ No } & \multirow{2}{*}{ Sample } & \multicolumn{4}{|l}{ Parameters } \\
\cline { 3 - 6 } & & $\mathrm{pH}$ & COD & BOD & E-Coli \\
\hline $\mathbf{1}$ & Middle1 & 7.31 & 270 & 83.7 & 1400 \\
\hline $\mathbf{2}$ & Outlet 1 & 7.46 & 133.3 & 41.323 & 0 \\
\hline $\mathbf{3}$ & Inlet2 & 7.02 & 1203.3 & 373.023 & 700 \\
\hline $\mathbf{4}$ & Middle2 & 7.15 & 503.3 & 156.023 & 6400 \\
\hline $\mathbf{5}$ & Outlet2 & 7.43 & 226.67 & 70.2677 & 0 \\
\hline
\end{tabular}

1. $\mathbf{p H}$

Based on the graph below (Figure 5.3) it can be seen that the lowest $\mathrm{pH}$ is in inlet samples taken from KPP Gunung Asri I which is 7.02 while the highest is outlet samples taken from KPP Cempaka which is 7.46.

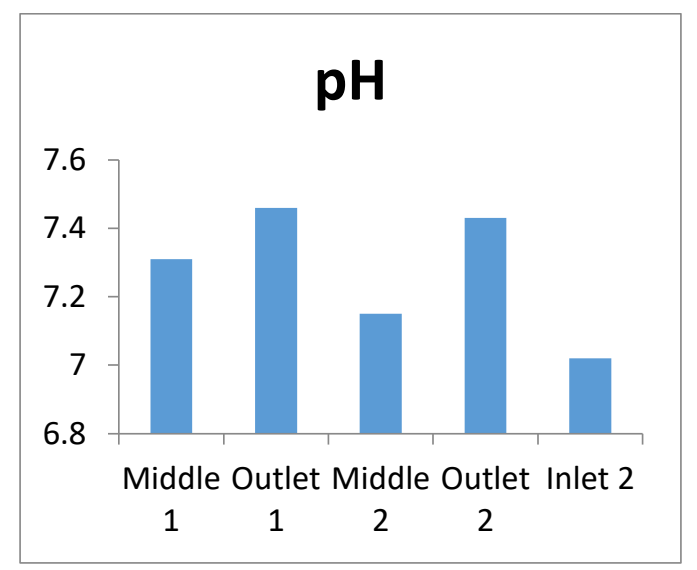

Fig.5.3. Graph of $p H$

\section{COD}

Based on the graph below (Figure 5.5) it can be seen that the lowest COD is in outlet samples taken from KPP Cempaka which is 133.3 while the highest is inlet samples taken from KPP Gunung Asri I which is 1203.3.

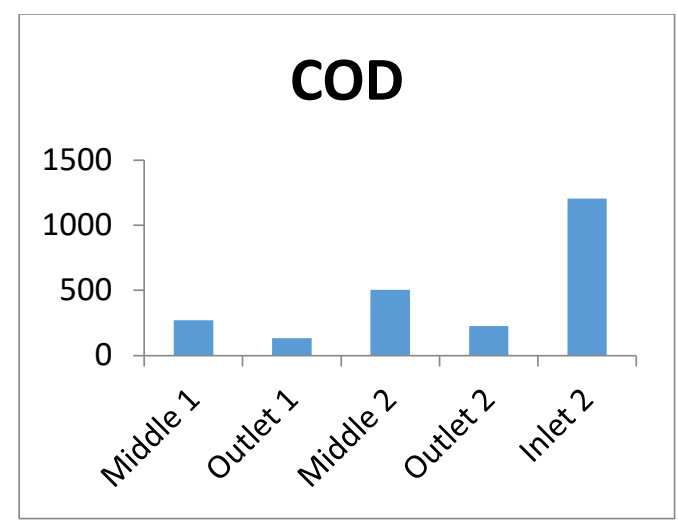

Fig.5.5: Graph of COD

\section{BOD}

Based on the graph below (Figure 5.6) it can be seen that the lowest BOD is in outlet samples taken from KPP Gunung Asri I which is 70.2677 while the highest is inlet samples taken from KPP Gunung Asri I which is 373.023.

\section{BOD}

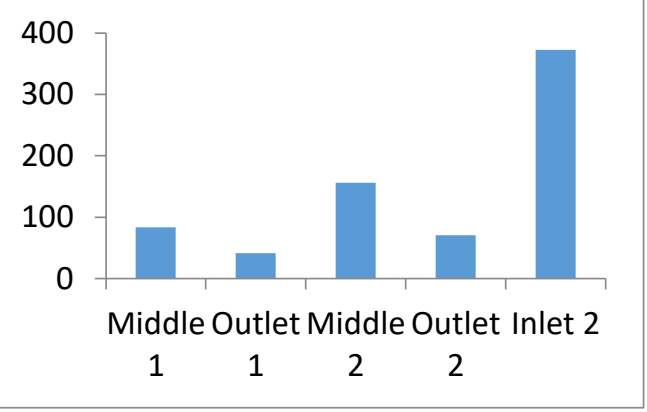

Fig.5.6: Graph of BOD

\section{E-Coli}

Based on the graph below (Figure 5.7) it can be seen that the lowest E-coli is in outlet samples taken from KPP Gunung Asri I and KPP Cempaka which is 0 while the highest is middle samples taken from KPP Gunung Asri I which is 6400 . 


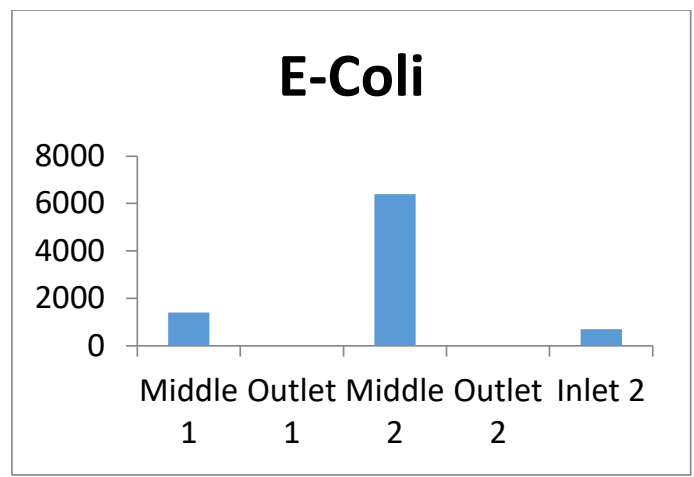

Fig. 5.7: Graph of E-Coli

\section{B. Discussion}

Based on the analysis results of, chemical and biological analysis, it can be seen that the sample that has the worst quality of waste is the waste from KPP Gunung Asri I which has the highest content of, COD, BOD and E-coli which allows that waste management at KPP Gunung Asri I is not going well.

The results of observations and analysis of several sample points obtained $\mathrm{pH}$ values between $7-8$. The acidity parameter is still within the threshold quality standards of class I to class IV river water according to Government Regulation No. 82 of 2001 which requires water $\mathrm{pH}$ ranging from 6-9 for classes I to III and 5-9 for class IV water. The degree of acidity $(\mathrm{pH})$ of water indicates the presence of hydrogen ions in the water. This is because hydrogen ions are acidic. Most aquatic biota are sensitive to changes in $\mathrm{pH}$ and prefer a $\mathrm{pH}$ value of 7 - 8.5 (Effendi, 2003).

\section{CONCLUSION}

Based on the result above can be concluded that:

1. The lowest $\mathrm{pH}$ is in inlet samples taken from KPP Gunung Asri I which is 7.02 while the highest is outlet samples taken from KPP Cempaka which is 7.46.

2. The lowest COD is in outlet samples taken from KPP Cempaka which is 133.3 while the highest is inlet samples taken from KPP Gunung Asri I which is 1203.3.

3. The lowest BOD is in outlet samples taken from KPP Gunung Asri I which is 70.2677 while the highest is inlet samples taken from KPP Gunung Asri I which is 373.023 .

4. The lowest E-coli is in outlet samples taken from KPP Gunung Asri I and KPP Cempaka which is 0 while the highest is middle samples taken from KPP Gunung Asri I which is 6400 .

\section{REFERENCES}

[1] Scalon, J, Cassar, A, Nemes, N. 2004. Water as Human Right?, IUCN Environmental Policy and Law Paper No.51. USA.

[2] Sharifinia M, Namin JI, Mahmoudifard A, Ramezanpour Z, Gholami K. 2016. Benthic diatom and macroinvertebrates assemblages, a key for evaluation of river health and pollution in the Shahrood River, Iran. Limnology 17 (1): 95-109.

[3] Halder, J.N. and Islam, M.N. (2015) Water Pollution and Its Impact on the Human Health. Journal of Environment and Human, 2, 36-46.

[4] Sahu, O. (2016). Degradation of colour and chemical oxygen demand of sugar industry wastewater by thermo-chemical combined processes. Environmental Nanotechnology, Monitoring \&amp; Management, 6, 194-205. Available at: https://doi.org/10.1016/j.enmm.2016.11.001

[5] Sharifinia, M., Mahmoudifard, A., Namin, J. I., Ramezanpour, Z., \&amp; Yap, C. K. (2016). Pollution evaluation in the Shahrood River: Do physico-chemical and macroinvertebrate-based indices indicate same responses to anthropogenic activities?. Chemosphere, 159, 584-594.

[6] Chow, VT, DR Maidment, LW Mays. 1988. Applied Hidrology. Amerika Serikat.

[7] Shiklomanov, IA. 1998. A Summary of The Monograph World Water Resources, Rusia.

[8] AlObaidy, A. H. M. J., Awad, E. S., Kadhem, A. J., \& Mashhady, A. A. Al. 2015. Evaluating Water Quality of Mahrut River, Diyala, Iraq for Irrigation, 33(4), 830-837.

[9] Corcoran, E., C. Nellemann, E. Baker, R. Bos, D. Osborn, H. Savelli, eds. (2010). Sick water? The central role of wastewater management in sustainable development. A rapid response assessment. Arendal, Norway: UNEP/GRID-Arendal.

[10] Tchobanoglous, G. dan Burton, F. L., 1991. Wastewater Engineering Treatment, Disposal, reuse. Series Water Resource and environmental engineering 6th ed. McGraw Hill Book Co., Singapore 